\title{
A random PWM control strategy for a three-level inverter used in a grid connected photovoltaic system
}

\author{
Kamal Himour ${ }^{1}$, K. Iffouzar ${ }^{2}$ \\ ${ }^{1}$ Department of Technology, University Center of El Bayadh, Algeria \\ ${ }^{2}$ Department of Second Cycle, School of Applied Sciences, Algeria
}

\begin{tabular}{|c|c|}
\hline Article Info & ABSTRACT \\
\hline Article history: & \multirow{7}{*}{$\begin{array}{l}\text { The work presented in this paper is devoted to the control of a photovoltaic } \\
\text { system connected to grid by a three-level diode clamed inverter. A control } \\
\text { structure based on three parts: dc link voltage control, power injected control } \\
\text { and current control is proposed. In this work, the random PWM strategy is } \\
\text { used to generate control signals for the multilevel inverter used us an } \\
\text { interface to connect photovoltaic generators to the grid. Numerical } \\
\text { simulations are performed using MATLAB/Simulink software, the } \\
\text { simulation results for the proposed system indicate the performances of the } \\
\text { proposed control structure, minimization of harmonics by the random PWM } \\
\text { strategy applied and injection to the grid more active power by the multilevel } \\
\text { inverter structure. }\end{array}$} \\
\hline Received Jan 22, 2020 & \\
\hline Revised Apr 4, 2020 & \\
\hline Accepted Apr 26, 2020 & \\
\hline Keywords: & \\
\hline Grid connection & \\
\hline Photovoltaic systems & \\
\hline
\end{tabular}

This is an open access article under the CC BY-SA license.

Three level inverters

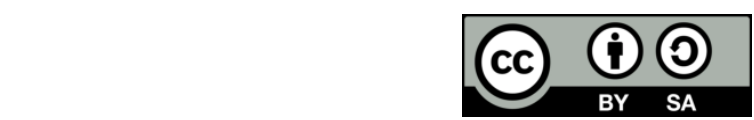

Corresponding Author:

Kamal Himour,

Department of Technology, Institute of Sciences,

University Center of El Bayadh,

BP 900, 32000, Algeria.

Email: himour.kamal@hotmail.fr

\section{INTRODUCTION}

Currently, renewable energies are considered as the alternative to fossil combustible in order to reduce pollution. The grid connected PV systems generally use a two-level inverter to send to grid the generated PV power, or it used to feed linear and nonlinear loads connected at the ac side [1-6]. Nevertheless, the conventional inverter is very limited in its output voltage levels. It only gives three levels of phase to phase output voltage and poor spectral quality [7-8]. To deal with this problem, researchers have proposed other structures called multilevel inverters to perform these grids connected photovoltaic systems such as: flying capacitors structure, the cascaded H-Bridge structure, the diode clamped inverters structure and the full bridge with cascaded transformers inverters. Theses multilevel inverters allow obtaining high output voltages with better spectral quality moreover; they offer several possibilities for the connection of photovoltaic generators or batteries to their continuous bus [9-14].

In literature, many works have used three level inverters in grid connected photovoltaic systems and proposed several control strategies for it. In [15], authors present the control of a three-level Neutral Point Clamped (NPC) voltage source inverter for grid connected photovoltaic (PV) systems; the control method used is the Extended Direct Power Control (EDPC), which is a generic approach for Direct Power Control (DPC) of multilevel inverters based on geometrical considerations. Also, in [16], authors used to control the three-level inverter, a modified version of voltage-oriented control (VOC) method and the space vector pulse width modulation (SVPWM) technique. To reduce the harmonic content of grid-connected current and to 
improve the dynamic response of the system, a single-carrier pulse width modulation method is presented for T-type three-level inverter in [17].

In this paper, a photovoltaic system connected to grid based on a three-level inverter which allows connection of one or two PV generators across the capacitors in the DC bus is proposed. The control structure proposed is composed of three parts: control of the DC bus voltage, control of power sent to network and current control. To control the three-level inverter, Random PWM control strategy is used. With this control strategy, the electromagnetic acoustic noise can be spread to the wideband area and a low THD of grid current can be obtained.

The paper is organized as follow: sections 2 illustrates the modelling of the proposed system, section 3 is devoted to the control of this proposed system, Then, in section 4 the simulation results are presented, finally in section 5 the conclusion of this study.

\section{MODELING OF THE PROPOSED SYSTEM}

The proposed system is shown in Figure 1. It consists of two photovoltaic generators connected to the three levels Diode Clamped Inverter through a DC bus; the multilevel inverter is connected to grid by a filter.

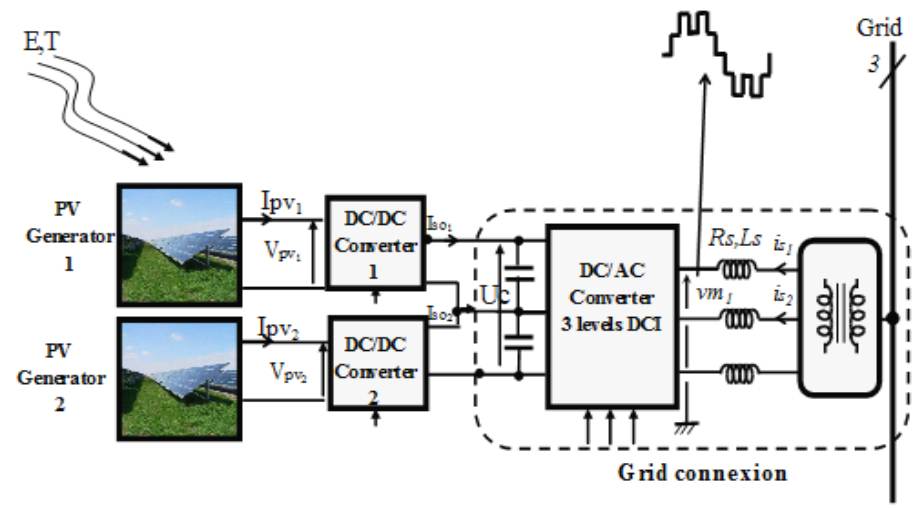

Figure 1. Proposed grid connected photovoltaic system structure.

\subsection{Photovoltaic generator modeling}

Solar cells are usually associated in series and in parallel, and then encapsulated under glass to obtain a photovoltaic module. PV modules are usually connected in series-parallel to increase the voltage and current at the photovoltaic generator output. The interconnected modules are mounted on metallic supports and inclined according to the desired angle depending on the location. Study and modeling of a photovoltaic generator and the I-V characteristic is based on a cell elementary modeled by the well-known equivalent circuit of Figure 2.

This circuit introduces a current source and a diode in parallel, as well as series resistance Rs and parallel resistance Rsh to take into account the dissipative phenomena [18].

$$
I=I_{p h}-I_{s}\left[\left(\exp \frac{V+I \cdot R_{s}}{m \cdot \frac{K \cdot T}{q}}\right)-1\right]-\frac{V+I \cdot R_{s}}{R_{s h}}
$$

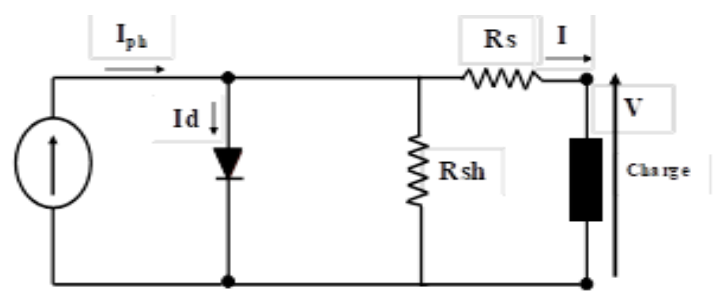

Figure 2. Photovoltaic cell equivalent circuit. 
For a PV module with $N_{s}$ series connected cells and $N_{p}$ parallel connected cells, the current- voltage characteristic is given by:

$$
I=N_{p} \cdot I_{p h}-N_{p} \cdot I_{s}\left[\exp \left\langle\left(\frac{1}{m \cdot K \cdot \frac{T}{q}}\right) \cdot\left(\frac{V}{N_{s}}+\frac{R_{s} \cdot I}{N_{p}}\right)\right\rangle-1\right]-\frac{N_{p}}{R_{s h}} \cdot\left(\frac{V}{N_{s}}+\frac{R_{s} \cdot I}{N_{p}}\right)
$$

Where:

$\mathrm{I}_{\mathrm{ph}}$ : The photo-current,

$\mathrm{I}_{\mathrm{s}}$ : The saturation current of diode,

$\mathrm{m}$ : ideality factor,

$R_{S}$ and $R_{s h}$ : series and parallel resistance,

$\mathrm{T}$ : junction temperature,

$\mathrm{K}$ : Boltzmann constant,

q: electron charge.

\subsection{Model of DC/DC converter}

The DC / DC converter used in this work is the most frequently used as boost converter (Boost) as shown in Figure 3.

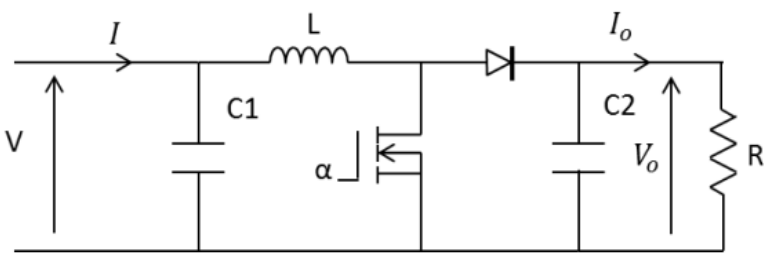

Figure 3. DC/DC Converter Structure.

This converter is modeled by the following equations:

$$
\begin{aligned}
& V_{o}=\frac{V}{(1-\alpha)} \\
& I_{o}=I \cdot(1-\alpha)
\end{aligned}
$$

Where $\alpha$, Vo and Io respectively denote the duty cycle, the voltage of output and the output current of the Boost converter. The cyclic ratio $\alpha$, is the MPPT control system output (P \& O).

\subsection{Model of three level diode clamped inverter}

A three-phase three-level diode-clamped inverter is shown in Figure 4 [19]. It is composed by three arms and two DC voltages. Each arm has four switches in series and two median diodes. Each switch consists of a transistor and an antipallel diode. The midpoint of each arm is connected to a DC source voltage (Uc). With a capacitive voltage divider formed by the filter capacitors $C_{1}$ and $C_{2}$ of same capacity $C$, we obtain two secondary DC sources each delivering a half voltage (Uc / 2). Being connected to each other at a neutral point noted $\mathrm{O}$.

For each leg of the inverter, we define three connection functions, each one is associated to one of the three states of the leg:

$$
\left\{\begin{array}{l}
F_{c 1 j}=F_{1 j} \cdot F_{2 j} \\
F_{c 2 j}=F_{2 j} \cdot F_{3 j} \\
F_{c 3 j}=F_{3 j} . F_{4 j}
\end{array}\right.
$$

As indicated in Table 1, each leg of the inverter can have three possible switching states $\mathrm{P}, \mathrm{O}, \mathrm{N}$. The output voltages of a three-level diode clamped inverter are expressed as follows: 
$\left[\begin{array}{l}V_{10} \\ V_{20} \\ V_{30}\end{array}\right]=\left[\begin{array}{lll}F_{c 11} & F_{c 21} & F_{c 31} \\ F_{c 12} & F_{c 22} & F_{c 32} \\ F_{c 13} & F_{c 23} & F_{c 33}\end{array}\right] \cdot\left[\begin{array}{l}\frac{U_{c}}{2} \\ 0 \\ \frac{-U_{c}}{2}\end{array}\right]$

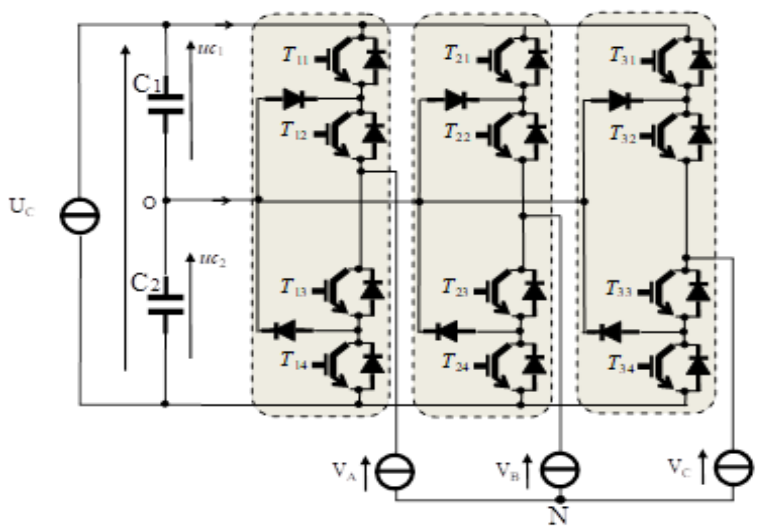

Table 1. States of one leg of 3 level DCI

\begin{tabular}{cccccc}
\hline$F_{k 1}$ & $F_{k 2}$ & $F_{k 3}$ & $F_{k 4}$ & $V_{k}$ & State \\
\hline 0 & 0 & 1 & 1 & $-U_{c} / 2$ & $\mathrm{~N}$ \\
0 & 1 & 1 & 0 & 0 & $\mathrm{O}$ \\
1 & 1 & 0 & 0 & $U_{c} / 2$ & $\mathrm{P}$ \\
1 & 0 & 0 & 1 & unknown & -
\end{tabular}

Figure 4. Three level diodes clamped inverter (DCI).

\section{THE PROPOSED CONTROL STRATEGY}

The objective of control structure is to regulate the DC-link voltage and to set a unit power factor. Figure 5 shows the whole bloc diagram of the control structure.

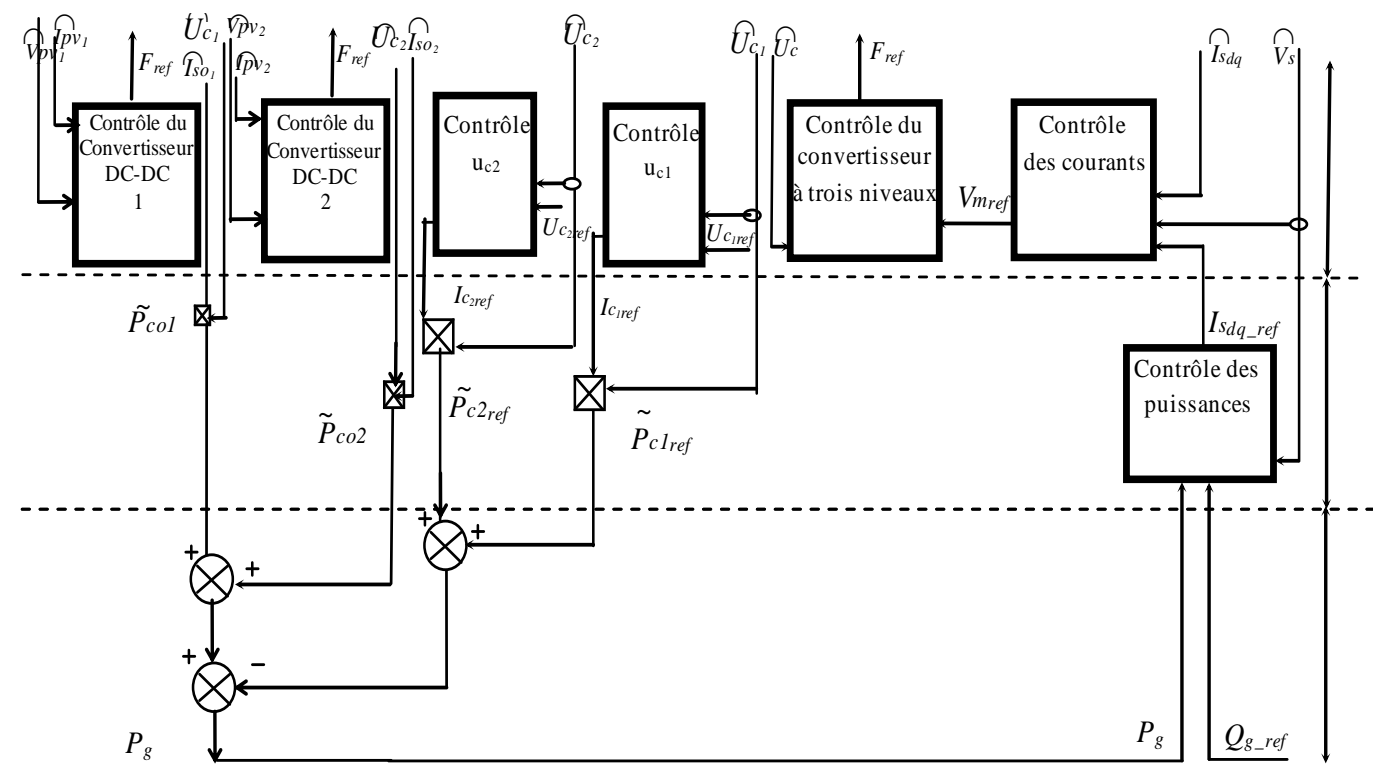

Figure 5. Bloc diagram of the control structure

\subsection{DC/DC converters control (MPPT control)}

The principle of this command is to generate disturbances by decreasing or increasing the cyclic ratio $\alpha$ and to observe the effect on the power delivered by the photovoltaic generator [20-21]. Its algorithm is illustrating in Figure 6. 


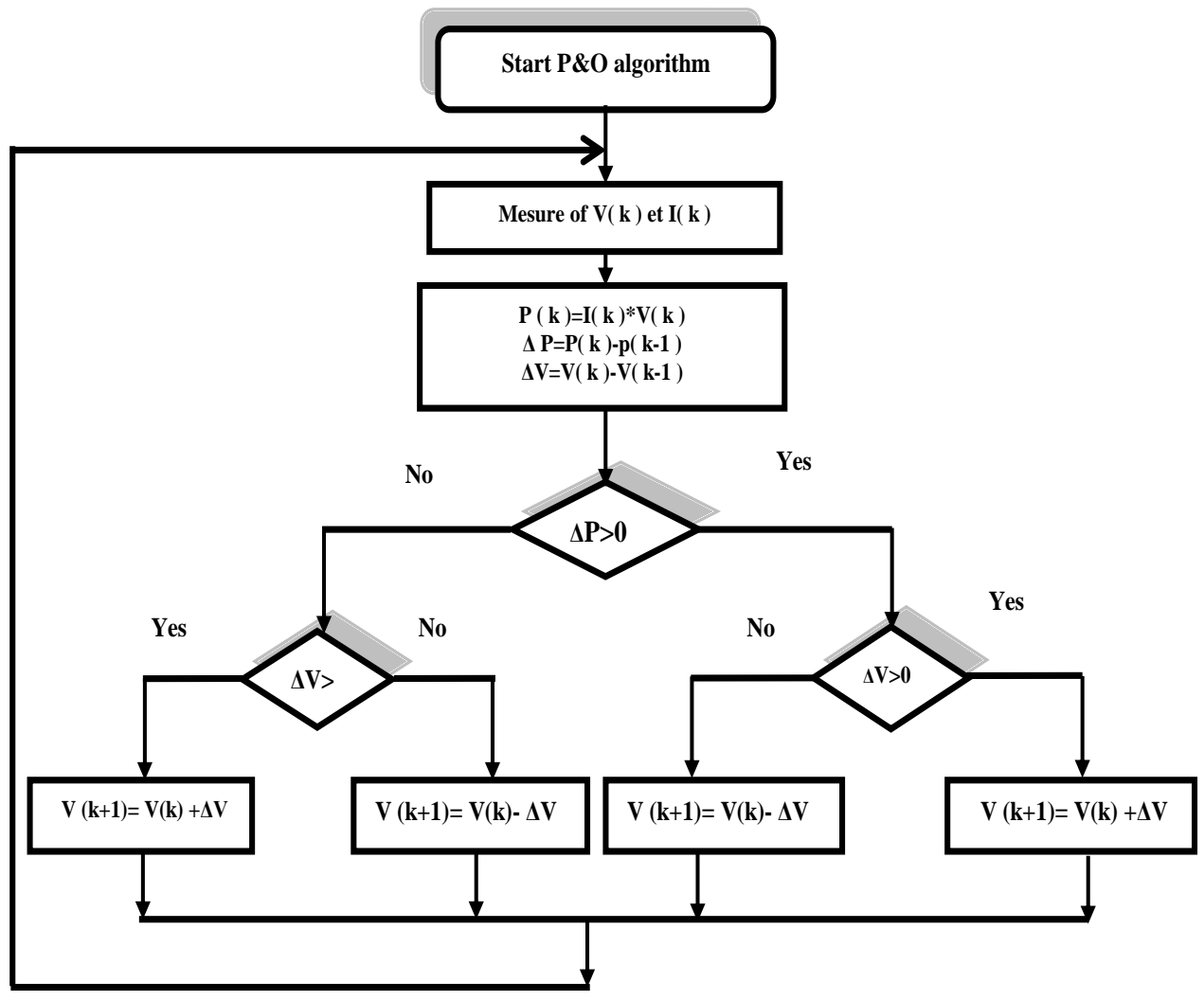

Figure 6. Flowchart of $\mathrm{P} \& \mathrm{O}$ algorithm.

\subsection{DC bus control}

The DC voltage corrector is used to regulate the DC bus and sets the active power $\boldsymbol{P}_{\text {gref }}$. Figure 7 illustrates the bloc diagram of DC voltage control.

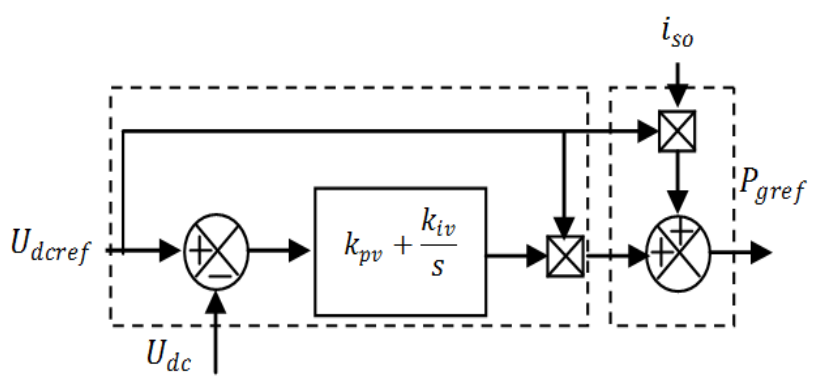

Figure 7. Bloc diagram of the DC bus control.

The DC link voltage must respect the condition:

$U_{d c \text { ref }}>\frac{\sqrt{3} V_{\text {fmax }}}{m_{\max }}$

Where:

$V_{\text {fmax }}$ : Maximum of phase voltage

$m_{\max }$ : Regulation index

The capacitance of the DC link is obtained by the relation: 
$C_{d c}=\frac{2 \cdot P_{\max } \cdot 20 \cdot 10^{-3}}{U_{d c}{ }^{2} \cdot\left(1-k^{2}\right)}$

Where: $k=\frac{U_{d c \min }}{U_{d c}}$

$P_{\max }:$ is the maximal power of the photovoltaic generator

The voltage $U_{d c \min }$ must be carefully chosen to ensure the controllability of the current at all operating points.

\subsection{Power control}

The active and reactive power $\left(\boldsymbol{P}_{g}, \boldsymbol{Q}_{g}\right)$ can be both expressed by using Park components of supply voltage $\left(\boldsymbol{V}_{\boldsymbol{t} \boldsymbol{d}}, \boldsymbol{V}_{\boldsymbol{t} \boldsymbol{}}\right)$ and line current $\left(\boldsymbol{I}_{\boldsymbol{t} \boldsymbol{d}}, \boldsymbol{I}_{\boldsymbol{t} \boldsymbol{}}\right)$ as follows:

$$
\left\{\begin{array}{l}
P_{g}=V_{t d} \cdot I_{t d}+V_{t q} \cdot I_{t q} \\
Q_{g}=V_{t d} \cdot I_{t q}-V_{t q} \cdot I_{t d}
\end{array}\right.
$$

Reference currents $\left(\boldsymbol{I}_{\text {tdref }}, \boldsymbol{I}_{\text {tqref }}\right)$ which allows setting the desired reference active and reactive powers $\left(\boldsymbol{P}_{\text {gref }}, \boldsymbol{Q}_{\text {gref }}\right)$, as follows:

$$
\left\{\begin{array}{l}
I_{\text {tdref }}=\frac{P_{\text {gref }} \cdot V_{t d}-Q_{\text {gref }} \cdot V_{t q}}{V_{t d^{2}}+V_{t q}{ }^{2}} \\
I_{t d r e f}=\frac{P \text { gref } V_{t q}-Q_{\text {gref }} \cdot V_{t d}}{V_{t d^{2}}+V_{t q}{ }^{2}}
\end{array}\right.
$$

The unity power factor is obtained simply by setting the reactive power reference null. We can also generate or absorbe $\left(Q_{\text {gref }}<0\right.$ or $\left.\quad Q_{\text {gref }}>0\right)$.

\subsection{Current control}

The vector current control in Park reference frame is carried out by using the synchronized reference with the grid voltage. Bloc diagram as shown in Figure 8. The electric equations of the filter $\left(R_{t}, L_{t}\right)$ connected to the grid are given bellow:

$$
\left\{\begin{array}{l}
V_{t d}=R_{t} I_{t d}+L_{t} \frac{d I_{t d}}{d t}-\omega_{s} L_{t} I_{t d}+V_{s d} \\
V_{t q}=R_{t} I_{t d}+L_{t} \frac{d I_{t q}}{d t}-\omega_{s} L_{t} I_{t q}+V_{s q}
\end{array}\right.
$$

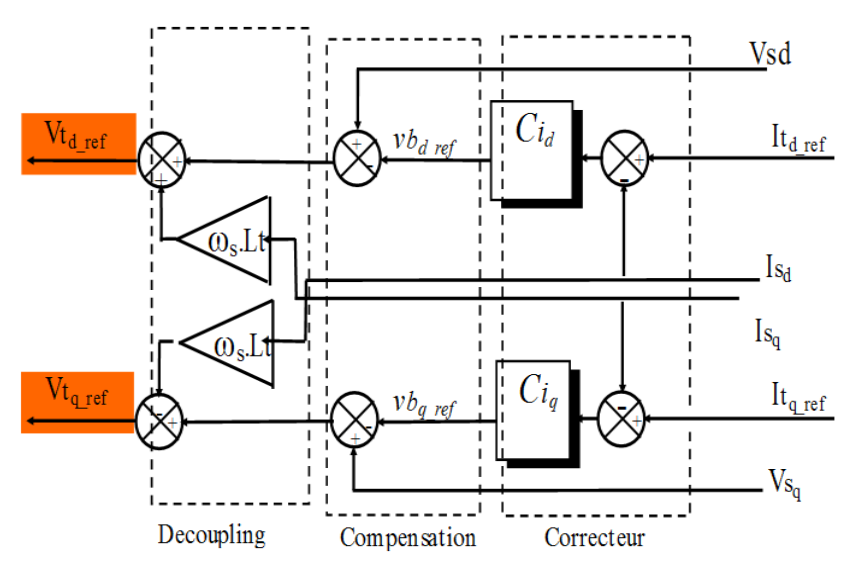

Figure 8. Bloc diagram of the current control

\subsection{Random PWM control strategy for the three levels DCI}

The PWM based on the comparison between the carrier wave which is in the most time triangular and the reference wave which is even provide directly by the programmer or by the far control technique like 
scalar or vector speed control. the switching instants depend the intersection between the two waves, in the PWM with a fix switching frequency the harmonics currents are shifted to the high frequencies which is good for the electrical point of view because the THD is low but for the others point of view it's different. The harmonics are very concentrated around the $m$ rang $\left(m=\frac{\text { carrier wave frequency }}{\text { reference wave frequency }}\right)$. so, we find that the highest harmonics are the $m \pm 2$ than $m \pm 4$ etc..., the same with $2 m$ and $3 m$ and all the " $m$ " multiple what we called harmonics families.

The method is based on a random selection of the carrier frequency for each carrier period [22-25]. In this technique the randomization of frequency of carrier wave is by taking some times the carrier wave and the other times the inverse of carrier wave. So, for do this we work with PRBS (the random bits generator, Figure 9 which it generates random bites even 0 or 1 .

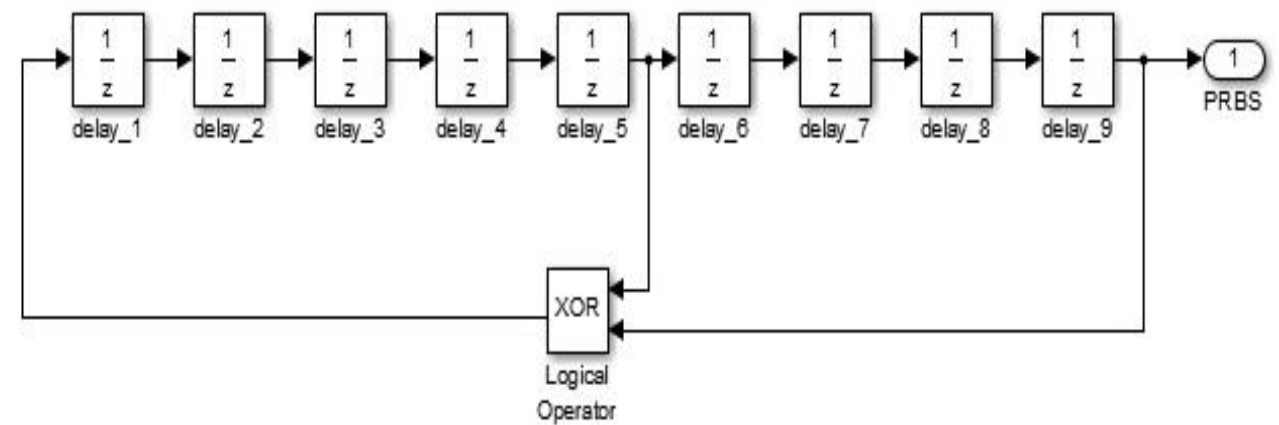

Figure 9. PRBS 9 bits scheme

In our scheme, PRBS signal is generated using a linear feedback shift register (LFSR), shown in Figure 9. It has 9 data storing units (delay line in optics), each unit is capable of storing one bit of binary data temporarily during one clock period. The whole system is synchronized with a clock. At each period, the 5 and 9 bit goes through a XOR process. The XOR logic is used in the PRBS to drive the input bit with the XOR of some bits of the overall shift register value, also A XOR gate can give very short pulse duration ( $<1 \mathrm{ps).} \mathrm{Then,} \mathrm{we} \mathrm{take} \mathrm{the} \mathrm{result} \mathrm{of} \mathrm{PRBS} \mathrm{and} \mathrm{multiple} \mathrm{with} \mathrm{the} \mathrm{carrier} \mathrm{wave} \mathrm{and} \mathrm{the} \mathrm{inverse} \mathrm{of} \mathrm{PRBS}$ multiple with the inverse of carrier wave and add the both results like it's been shown in Figure 10 and Figure 11. By using the PRBS scheme and the carrier wave and the reference scheme we can build the bloc of PRWM with pseudorandom carrier.

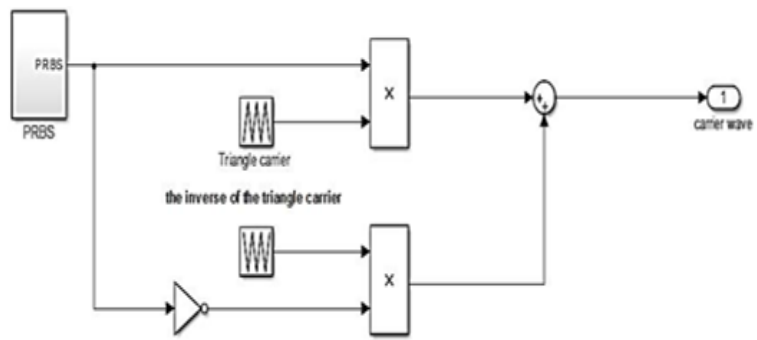

Figure 10. Carrier wave generation

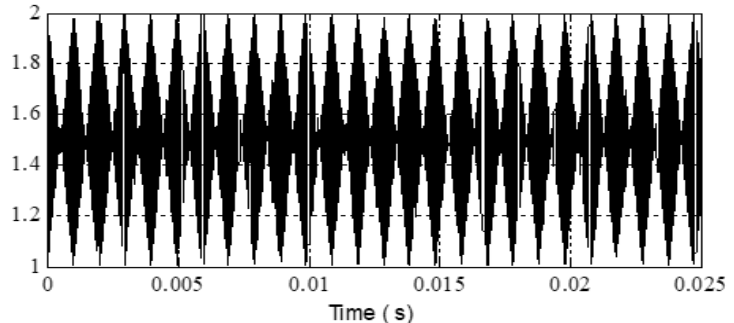

Figure 11. Carrier wave form

\section{SIMULATION RESULTS}

In this section, the proposed photovoltaic grid connection system is simulated using MATLAB/Simulink. We have connected two PV generators (each generator is composed of 13 panels of 150 $\mathrm{W}$ put in series) to the continuous bus as shown in Table 2. The reactive power is controlled by controlling in park frame the injected currents in the grid, we impose a grid reactive power equal to zero $\left(Q_{\text {ref }}=0\right)$, and the reference active power is calculated by the DC bus control bloc. 
Table 2. Proposed system parameters

\begin{tabular}{|c|c|c|c|}
\hline \multicolumn{4}{|c|}{ Photovoltaic array Bps 150} \\
\hline$\overline{P_{\max }}$ & 150 & $\mathrm{~W}$ & Maximal power \\
\hline $\mathrm{V}_{\mathrm{op}}$ & 34.5 & $\mathrm{~V}$ & Optimal voltage \\
\hline $\mathrm{I}_{\mathrm{op}}$ & 4.35 & A & Optimal current \\
\hline $\mathrm{V}_{\mathrm{oc}}$ & 43.5 & V & open circuit voltage \\
\hline $\mathrm{I}_{\mathrm{cc}}$ & 4.75 & A & Short circuit current \\
\hline $\mathrm{N}_{\mathrm{s}}$ & 5 & / & Number of series arrays \\
\hline $\mathrm{N}_{\mathrm{p}}$ & 0 & / & Number of parallel arrays \\
\hline & & & DC Bus \\
\hline $\mathrm{U}_{\mathrm{dc}}$ & 624 & V & DC bus voltage \\
\hline $\mathrm{C}$ & 0.41 & $\mathrm{mF}$ & Capacitance of DC bus \\
\hline & & & Filter \\
\hline $\mathrm{R}_{\mathrm{t}}$ & 3 & $\Omega$ & Filter resistance \\
\hline $\mathrm{L}_{\mathrm{t}}$ & 0,05 & $\mathrm{H}$ & Filter inductance \\
\hline & & & Grid \\
\hline $\mathrm{V}_{\mathrm{s}}$ & 380 & $\mathrm{~V}$ & Voltage \\
\hline $\mathrm{F}$ & 50 & $\mathrm{~Hz}$ & frequency \\
\hline
\end{tabular}

Figure 12 shows $\mathrm{P}(\mathrm{V})$ and $\mathrm{I}(\mathrm{V})$ curves for $\mathrm{PV}$ panel. The profiles of irradiance of two PV generators are shown in Figure 13.
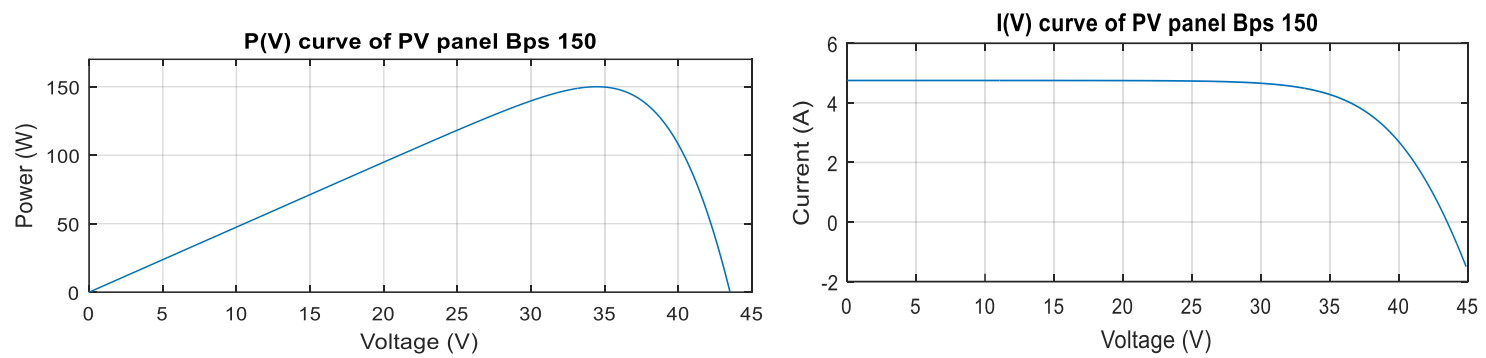

Figure 12. P (V) and I (V) curves for PV panel.

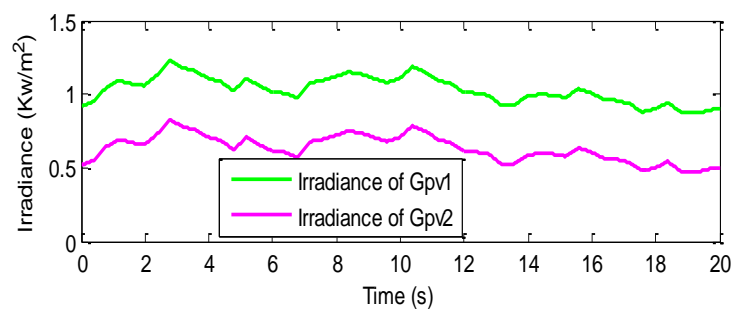

Figure 13. Irradiance profile of each PV generator

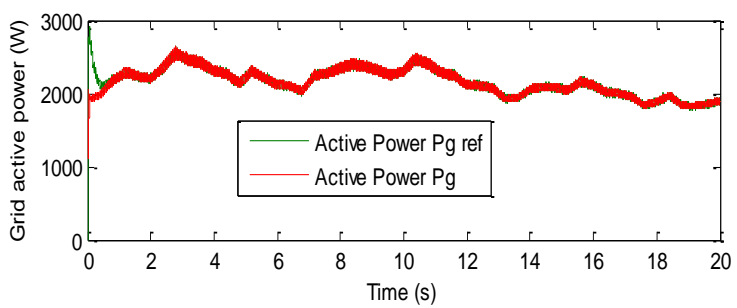

Figure 15. Grid active power

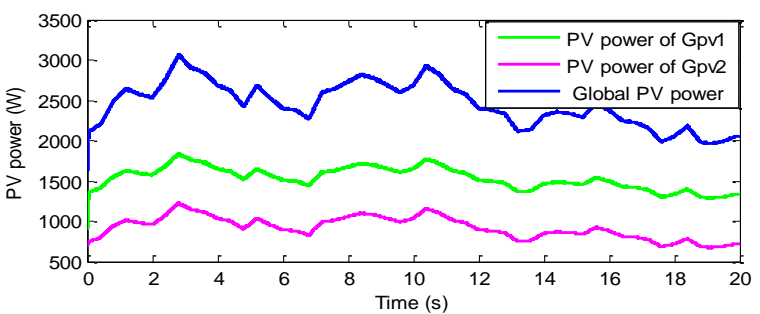

Figure 14. PV power of each PV generator and global PV power

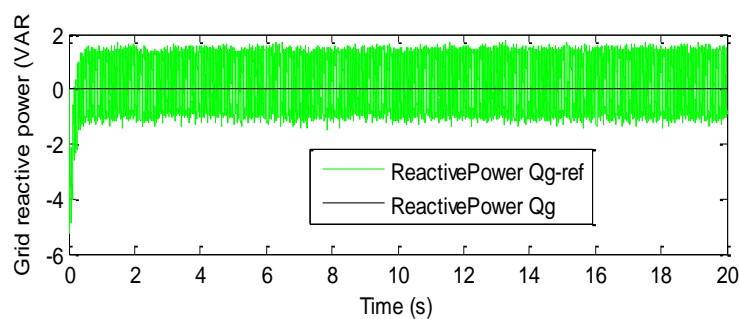

Figure 16. Grid reactive power 


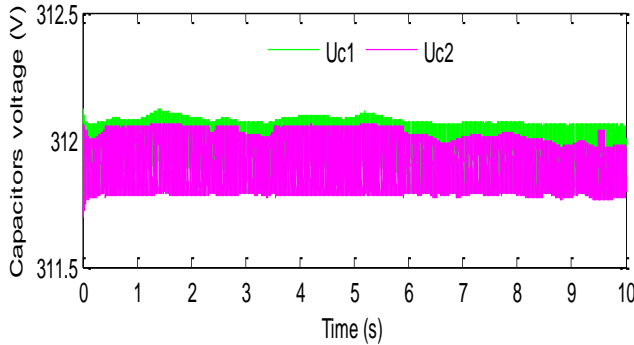

Figure 17. Voltages $\mathrm{U}_{\mathrm{c} 1}$ and $\mathrm{U}_{\mathrm{c} 2}$

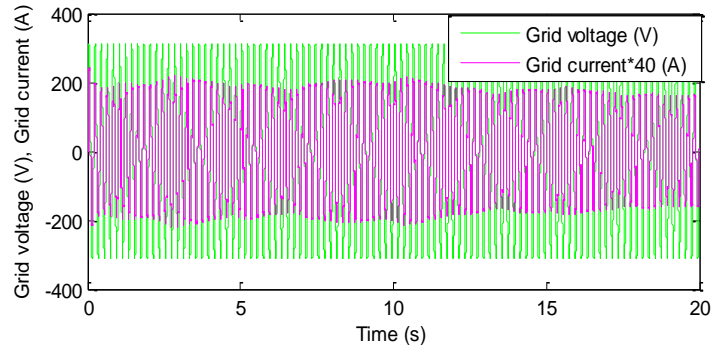

Figure 18. Grid voltage and current

Figures 14, 15 and 16 respectively show the total produced photovoltaic power, the active power and the reactive power transmitted to the electrical network. These results show that all the PV power produced is injected to grid with a unit power factor because we have imposed a reference reactive power equal to 0. Figure 17 shows the voltages of the two capacitances of the DC bus. The two capacitance are equal $\left(\mathrm{C}_{1}=\mathrm{C}_{2}=0.2 \mathrm{mF}\right)$. the grid voltage and the grid current of phase 1are illustrated in Figure 18. Figures 19 and 20 respectively represent the output voltage of the three levels DCI and its harmonic analysis $(T H D=35.40 \%)$.

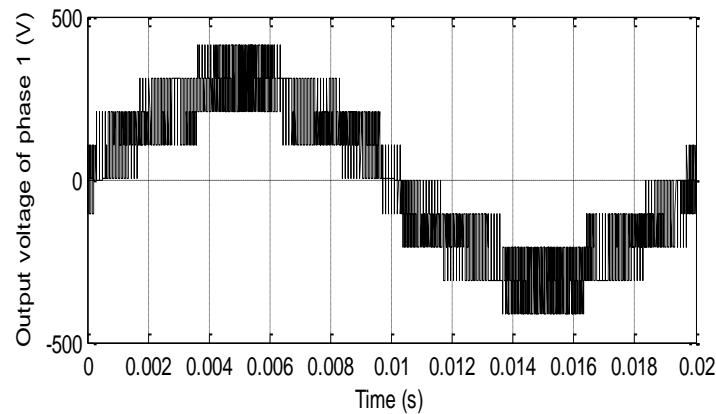

Figure 19. Output voltage of phase 1 of the 3 level DCI

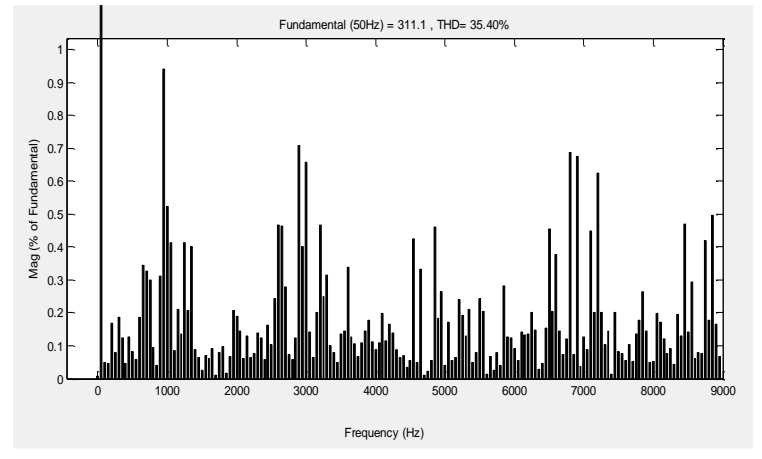

Figure 20. Harmonic analysis of output voltage $\mathrm{V}_{1}$

\section{CONCLUSION}

This paper presents the advantages of three level diodes clamped inverter for grid connected photovoltaic systems. The proposed system produces less $\mathrm{dv} / \mathrm{dt}$ stresses imposed on the switching devices and generates fewer harmonic in voltage and current by using Random PWM control strategy. The using of three levels DCI, allows connecting two PV generators to the grid. Also, it possible to transmit more power to grid by increasing the DC bus voltage, and a reduction of the filter elements. The circuit provides good decoupling of the voltage loops $\mathrm{V}_{\mathrm{d}}$ and $\mathrm{V}_{\mathrm{q}}$ since the $\mathrm{V}_{\mathrm{q}}$ remains constant under variations which shows high dynamic performances of the controllers. Thus, the active and reactive power follows quietly the reference signals. The grid voltage and current are in phases there by the power factor at the grid connection is almost unity.

\section{REFERENCES}

[1] Samir Kouro, Jose I. Leon, Dmitri Vinnikov, Leopoldo G. Franquelo, "Grid-Connected Photovoltaic Systems: An Overview of Recent Research and Emerging PV Converter Technology," in IEEE Industrial Electronics Magazine, March 2015.

[2] J Sreedevi, N Ashwin, M Naini Raju, "A study on grid connected PV system," in National Power Systems Conference (NPSC), pp. 1-6, 2016.

[3] K.N. Nwaigwe, P. Mutabilwa, E. Dintwa, "An overview of solar power (PV systems) integration into electricity grids”, Materials Science for Energy Technologies, pp. 629-633, 2019.

[4] Gustavo Hunter, Javier Riedemann, Iván Andrade, Ramón Blasco-Gimenez \& Rubén Peña, "Power control of a grid-connected PV system during asymmetrical voltage faults” Electrical Engineering, vol. 101, pp. 239-250, 2019. 
[5] V.C. Sontake and V.R. Kalamkar, "Solar photovoltaic water pumping system - A comprehensive review," Renewable and Sustainable Energy Reviews, vol. 59, pp. 1038-1067, 2016.

[6] S.S. Chandel, M. Nagaraju Naik, Rahul Chandel, "Review of solar photovoltaic water pumping system technology for irrigation and community drinking water supplies," Renewable and Sustainable Energy Reviews, vol. 49, pp 1084-1099, 2015.

[7] Meynard, T.A.; Foch, "H. Multi-level conversion: High voltage choppers and voltage-source inverters," In IEEE Power Electronics Specialists Conference, Toledo, Spain, pp. 397-403, 1992.

[8] Ronak A. Rana, Sujal A. Patel, Anand Muthusamy, Chee woo Lee, and Hee-Je Kim, "Review of Multilevel Voltage Source Inverter Topologies and Analysis of Harmonics Distortions in FC-MLI," Electronics, vol. 8, no. 11, p. 1329, 2019.

[9] V S Prasadrao K, P Sudha Rani and GandhamTabita, "A new multilevel inverter topology for Grid interconnection of PV systems," PESTSE, pp. 1-5, 2014.

[10] K. S. Srikanth, "A Three Phase Multi Level Converter for Grid Connected PV System," International Journal of Power Electronics and Drive System (IJPEDS), vol. 5, no. 1, pp. 71-75, 2014.

[11] Deshpande, Soham G. and N. R. Bhasme, "A review of topologies of inverter for grid connected PV systems," In 2017 Innovations in Power and Advanced Computing Technologies (i-PACT), pp. 1-6, 2017.

[12] K. Himour, K. Ghedamsi and E.M. Berkouk, "Supervision and control of grid connected PV-storage systems with the five-level diode clamped inverter," Energy Conversion and Management, vol. 77, pp. 98-107, 2014.

[13] Zicheng Zhang, Alian Chen, Xiangyang Xing, Chuoran Zhang, "Space vector modulation based control strategy of three-level inverter for separate MPPTs in photovoltaic system," in IEEE 8th International Power Electronics and Motion Control Conference (IPEMC - ECCE Asia), 2016.

[14] Sandeep. N, Udaykumar R.Y, "Single Phase Seven Level Grid Connected Photovoltaic System with Ripple Correlation Control Maximum Power Point Tracking," International Journal of Renewable Energy Research, vol. 6 , no. 4,2016 .

[15] JaimeAlonso, Martınez Joaquin, Eloy-Garcia, Santiago Arnaltes, "Direct power control of grid connected PV systems with three level NPC inverter," Solar Energy, vol. 84, no. 7, pp. 1175-1186, 2010.

[16] GeorgiosTsengenes, GeorgiosAdamidis, "A multi-function grid connected PV system with three level NPC inverter and voltage oriented control," Solar Energy, vol. 85, no. 11, pp. 2595-2610, 2011.

[17] Zhi Zhang and Hao Zhou, "High performance of three-level T-type grid-connected photovoltaic inverter system with three-level boost maximum power point tracking converter," Advances in mechanical engineering, 2019.

[18] Omar Mohammed Benaissa, Samir Hadjeri, Sid Ahmed Zidi, "Modeling and Simulation of Grid Connected PV Generation System Using Matlab/Simulink," International Journal of Power Electronics and Drive System (IJPEDS), vol. 8, no. 1, pp. 392-401, 2017.

[19] Akash S. Pabbewar, M. Kowsalya, "Three Level Neutral Point Clamped Inverter Using Space Vector Modulation with Proportional Resonant Controller,” Energy Procedia, vol. 103, pp. 286-291, 2016.

[20] Subudhi B, Pradhan R, "A comparative study on maximum power point tracking techniques for photovoltaic power systems," IEEE Trans Sustain Energy, vol. 4, no. 1, pp. 89-98, 2012.

[21] Gupta AK, Saxena R, "Review on widely-used MPPT techniques for PV applications," in International conference on innovation and challenges in cyber security (ICICCS-INBUSH), pp 270-273, 2016.

[22] Sreeja P, L. Padmasuresh, P. Muthukumar, "Fpga Based Random Pulse Width Modulation for Three Phase VSI," International Journal of Recent Technology and Engineering (IJRTE), vol. 8, no. 2S6, 2019.

[23] Young-cheol Lim, Seog-Oh Wi, Jong-Nam Kim, Young-Gook Jung, "A Pseudo random Carrier Modulation Scheme", IEEE Transactions on Power Electronics, vol. 25, no. 4, pp. 797-805, 2010.

[24] Paramasivan, M., Paulraj, M. M., \& Balasubramanian, S., "Assorted carrier-variable frequency-random PWM scheme for voltage source inverter," IET Power Electronics, vol. 10, no. 14, pp. 1993 -2001, 2017.

[25] Varadharajan Krishnakumar, V. Kamaraj, S. Jeevananthan, "Random Pulse Width Modulation Technique for Performance Improvement of Multilevel Inverter Brushless DC Motor Drive," Australian Journal of Basic and Applied Sciences, vol. 9, no.16, pp. 162-171, 2015. 